\title{
Anxiety and Individual Coping Strategies in Undergoing Isolation During The Covid-19 Pandemic
}

\author{
Ismiyati Yuliatun $^{1 *}$, Siti Rahmawati ${ }^{2}$, Sri Lestari $^{3}$ \\ 1,2,3 Master of Psychology, Muhammadiyah University of Surakarta, A.Yani Mendungan Pabelan Kartasura \\ Sukoharjo 57169, Jawa Tengah, Indonesia \\ ${ }^{1}$ Surakarta Mental Hospital, KH. Dewantara 80 Jebres Surakarta 57162, Surakarta, Indonesia \\ *Email: S30020009@student.ums.ac.id \\ *Corresponding author \\ Submission date: 28 Januari 2021, Receipt date: 16 Maret 2021, Publication date: 1 April 2021
}

\begin{abstract}
The accuracy of copinging strategies needed to overcome anxiety during isolation. The purpose of this study was to find out how the anxiety experienced and how the individual's coping strategies deal with anxiety while undergoing isolation during the Covid-19 pandemic. The research method was qualitative with phenomenological studies. Data was collected using semi-structured interviews and observations of two mothers who underwent isolation. The data obtained were analyzed to find emerging themes. There are five main themes, namely, conditions before isolation affect conditions during isolation. anxiety is caused by external and internal factors. The Symptoms of anxiety, coping strategies that stand out in spiritual and support, effects of coping strategies, and lessons learned during isolation add to family harmony.
\end{abstract}

Keywords: anxiety, coping strategy, covid-19, isolation

\section{INTRODUCTION}

The most common symptoms of COVID-19 are fever, dry cough, and feeling tired. In some people, these symptoms appear gradually and worsen over time, but some people only experience mild symptoms. Positive Rapid or RTPCR test results with or without symptoms can have a psychological impact on a person, wherewith a positive diagnosis of Covid-19, various consequences must be carried out. Patients must do isolation, whether it is self-isolation because there are no symptoms until mild symptoms, or isolation in hospital for severe patients. WHO, fear, stress, and worry are normal reactions when people face threats and uncertain situations, such as in Covid-19. This can affects the physical and mental condition. (WHO, 2020).

According to Law no. 6 of 2018, isolation is carried out by separating sick people from healthy people in health care facilities to get treatment. Treatment for everyone is obliged to comply with the implementation of health isolation or quarantine. Isolation in people without symptoms and mild symptoms carried out at home for 14 days. People with symptoms are isolated at the covid-19 hospital for 14 days or referred to a covid-19 referral hospital. 


\section{Isolation during the Covid-19 Pandemic}

According to Oktavia \& Hayati (2020), the definition of isolation independently carries out an activity of separation from someone who has an infectious disease. Isolation during the covid-19 pandemic is a condition carried out to separate sick people from healthy people in health care facilities to get care and treatment. Everyone is obliged to comply with the implementation of health isolation or quarantine. In the Covid-19 pandemic situation, isolation of people without symptoms and mild symptoms is carried out at home for 14 days. People with symptoms are isolated at the Covid-19 hospital for 14 days or referred to the Covid-19 Hospital. This regulation is under the rules of Law no. 6 of 2018 concerning Health Quarantine.

Implementing this isolation can cause various problems, including health anxiety, worries about the family, reduced or even cessation of family livelihoods, and unbalanced communication with family and other people. All of these are drastic changes in people's lives. Community attitudes that give a negative stigma can also cause pressure or stress. According to WHO (2019), stress during a pandemic can appear in the form of fear and anxiety about personal health and the health of other loved ones, changes in sleep patterns or eating patterns, difficulty concentrating. This condition aggravates a person who has a history of chronic diseases and psychological disorders and uses drugs.

According to Brooks et al. (2020), distress and anxiety are normal reactions to threatening and unexpected situations such as the Covid-19 virus. Possible stress-related reactions to the Covid 19 virus can include changes in concentration, irritability, anxiety, insomnia, reduced productivity, and interpersonal conflicts. Apart from the threat by the virus itself, there is no doubt that isolation has a negative and stress-increasing effect. The severity of symptoms depends partly on the duration or extent of isolation, feelings of loneliness, fear of infection, adequate information and stigma, among more vulnerable groups, including psychiatric disorders, health care workers, and people with low socioeconomic status.

Nurjanah (2020) found that ten people (33.3\%) had mental-emotional disorders that occurred in Covid pandemic clients $(33.3 \%)$ with the most complaints, namely feeling anxious, tense/worried (40\%), complaints of activity / neglected daily tasks (37\%), loss of appetite (30\%) and poor sleep (30\%).

The anxiety experienced by individuals when undergoing isolation, if not resolved immediately, can become heavier and will continue even though the isolation period has ended. Individuals still feel worried, emotionally unstable, experience sleep disturbances, and even cause traumatic conditions.

Based on the Covid-19 pandemic survey, it was found that 64.8 percent of the 4010 people who carried out self-examinations experienced psychological problems of anxiety or depression after conducting independent online checks related to mental health as a result of the Covid-19 pandemic (PDSKJI, 2020). The informants' main symptoms of anxiety felt that something terrible would happen, excessive worry, irritability or irritation, and difficulty relaxing. Informantexperiencing excessive fear and worry, feeling uneasy and comfortable, 
experiencing sleep disturbances, and being overly alert. The survey results also stated that women who experienced the most anxiety or depression were 76.1 percent, with a minimum age of 14 years and a maximum of 71 years.

\section{Anxiety}

Anxiety is a reaction that anyone can experience. However, excessive anxiety, especially those that have become a nuisance, will hinder one's function in life (Kaplan et al., 2010)

According to Mai et al. (2020), the symptom of anxiety experienced by Covid-19 patients undergoing isolation is that they are worried about whether the child/family at home will be cared for properly. Even though the patient's symptoms have improved, they are still worried about the fluctuation of their condition, and the patient becomes nervous and anxious. The factors that affect the level of anxiety of Covid-19 patients include internal and external factors. The internal factors, namely physical health conditions (cough, shortness of breath, fever, lack of rest, decreased sleep quality, and others). The external factors, namely factors that arise due to environmental and social changes such as news about many victims who have fallen, many Covid-19 patients who have died, reduced social contact and communication. (Jannah et al., 2020).

Decreased psychological conditions cause the anxiety experienced by Covid-19 patients during isolation due to limited social contact with the environment, the emergence of quite severe physical symptoms, thinking about other family conditions / those at home, and hearing / seeing news of fallen victims. (Tanoue et al., 2020).

Mai et al. (2020) found that hospitalized or isolated patients often experience sleep disturbances, depression, and anxiety. The anxiety that arises is partly due to isolation conditions and concerns about developing the Covid 19 virus in society.

There have been drastic changes with limited knowledge about Covid-19, resulting in health shocks that can cause overreaction and panic. This drastic change requires a person to be able to have the right coping strategy. According to Adwin et al., 1987), a coping strategy is a method or method used by each individual to overcome and control situations or problems seen as obstacles, painful challenges, such as harmful threats. In isolation due to being positive for Covid-19, a person must choose the right coping strategy that adapts to drastic changes.

\section{Coping Strategy}

Coping strategy is a defense mechanism in the process of psychological adaptation to the environment. (Nicolas \& Sandal, 2013).

According to Lazarus \& Folkman (1984), coping strategies are actions taken by individuals to overcome the adverse effects caused by anxiety. Several factors influence coping strategies, such as health conditions, economic conditions, personality, self-concept, and social support. 
The forms of coping strategies commonly used by individuals can be divided into two, namely, coping strategies that focus on problems and coping strategies that focus on emotions.

Previous research has suggested that one of the coping strategies that can practice during isolation is relaxation exercises. Relaxation can be an alternative to support the personal adaptation process to help reduce/eliminate anxiety. (Aufar \& Raharjo, 2020). Practicing to adjust and try to enjoy the condition that you are experiencing is also a coping strategy to divert feelings of anxiety. (Muslim, 2020).

Lazarus (1991) suggests that coping strategies become a factor that determines the human ability to make adjustments to stressful situations (stressful life events). The right coping strategy, it will reduce the psychological pressure or anxiety experienced.

Several studies have revealed anxiety and the psychological impact on health workers who care for Covid-19 patients (Rosyanti et al., 2020; Antara, 2020). Research on relaxation, mindfulness, and self-talk activities as a stress coping to reduce tension or anxiety during a pandemic has also been carried out (Ananda \& Apsari, 2020; Aufar \& Raharjo, 2020; Weis, 2020). The research was carried out extensively in the general public. Research on anxiety and coping strategies in individuals during isolation during the pandemic with family members who are also positive for Covid-19 is still rare.

From the above explanation, it can conclude that being attacked by Covid19 can cause problems in mental health such as experiencing anxiety, stress, and fear. The covid survivor does not have sufficient knowledge about efforts to care for and take care of themselves while undergoing a period of independent isolation. Therefore, this study aims to obtain an overview of the individual's experience of isolation and the coping strategies during the isolation period.

This study can help to increase the knowledge of informants in particular and society in general about the use of coping strategies to overcome the anxiety that arises both during isolation and in other situations.

\section{RESEARCH METHODS}

This study uses a qualitative method. According to Bogdan and Taylor, qualitative methodology is a research procedure that produces descriptive data in the form of written or oral sentences from people and observable behavior to emphasize the observation of a phenomenon. This study using a phenomenological perspective that focuses on subjective human experiences and their interpretations.

The informants in this study were two mothers who had undergone isolation during the Covid-19 pandemic with family members who were also positive for Covid-19. (Moelong, 2010). Informant data is in the table below. 
Table 1. Informant Data

\begin{tabular}{|c|c|c|c|c|c|c|}
\hline $\begin{array}{c}\text { Informant } \\
\text { (Initials) }\end{array}$ & Age & Profession & $\begin{array}{l}\text { Isolation } \\
\text { Place }\end{array}$ & $\begin{array}{l}\text { Duration } \\
\text { of } \\
\text { Isolation }\end{array}$ & $\begin{array}{l}\text { Positive / } \\
\text { Negative } \\
\text { Symptomatic } \\
\text { / Not }\end{array}$ & $\begin{array}{l}\text { Positive } \\
\text { family } \\
\text { members }\end{array}$ \\
\hline $\begin{array}{c}1 \\
(\mathrm{Hs})\end{array}$ & 53 years & $\begin{array}{l}\text { PTS } \\
\text { Admintrasi } \\
\text { Staff }\end{array}$ & Hospital & 23 days & $\begin{array}{l}\text { Positive } \\
\text { Symptomatic }\end{array}$ & $\begin{array}{l}\quad \text { Husband } \\
\text { Child } 1 \\
\text { person }\end{array}$ \\
\hline $\begin{array}{c}2 \\
(\mathrm{Sr})\end{array}$ & 52 years & Tailor & $\begin{array}{l}\text { Home } \\
\text { continued } \\
\text { Healthy } \\
\text { Home }\end{array}$ & $\begin{array}{l}30 \text { days } \\
\text { at home } \\
11 \text { days } \\
\text { at the } \\
\text { hospital }\end{array}$ & $\begin{array}{l}\text { Positive } \\
\text { Symptomatic }\end{array}$ & $\begin{array}{l}\text { Children } 3 \\
\text { people }\end{array}$ \\
\hline
\end{tabular}

The data collection methods used in this study are:

1. Interview

According to Moleong, an interview is a conversation with a specific purpose. Both parties carry out the conversation to construct about individuals, events, activities, organizations, feelings, demands, things experienced in the past, and expanding information obtained from other people.

The interview used is a semi-structured interview, namely the interview process that uses an interview guide that comes from the development of the topic and asks questions and uses it more flexibly than the interview.

During the interview, the data was recorded using a recording device to check for the correctness of the data so that its credibility was more guaranteed.

2. Observation

Observation is an activity of observing an object directly and in detail to find information about particular objects.

The observation method is carried out simultaneously with the interview, considering that these two methods support each other to obtain the desired data.

Data analysis was performed using the Thematic Analysis method, with steps; 1) understand the data by reading back the transcripts of data that have been made and listening to the recorded interviews during the data collection process, 2) compiling codes/labels from the data obtained, 3) arranging tentative themes based on the codes that have been made.

\section{RESULTS AND DISCUSSION}

Based on the research results, six themes related to anxiety and coping strategies were obtained during isolation during the Covid-19 pandemic, namely; 1) conditions before and during isolation, 2) factors causing anxiety, 3) symptoms 
of anxiety, 4) coping strategies and support, 5) effects of coping strategies, 6) wisdom of undergoing isolation.

\section{Conditions Before and During Isolation.}

a. Conditions before Isolation

The condition before being isolated describes the family background of each informant, where there is a difference between informant one (Inf-1) and informant two (Inf-2). The family background obtained is regarding; 1) family member, namely Inf-1 family with one child who is already in college, husband as ASN; while Inf-2, a family with six children and four people who are still in college, the husband works as a masseuse; 2) Hobbies were carried out during the pandemic period before the isolation, Inf-1 was doing sports and cooking, while Inf-2 was sewing as usual; 3) The particular situation obtained was that Inf-1 was a cadre whose job was to provide education to the public about Covid-19 as the statement conveyed:

... "Because I also often educate my neighbors on Covid, relatives, so it's normal." (Inf-1)

Meanwhile, Inf-2's family members are not used to drinking well water at home, so they have to buy drinking water supplies, as stated;

"If I am a child, I want water from the well to be boiled and it can also be drunk but from the water here I don't want to keep refilling but I don't want my child to make coffee but I don't want it from the first time I was here to buy this house. I have never drunk water from that well before .. "(Inf-2)

Conditions before isolation will affect a person's ability to adapt to situations experienced. DeLongis \& Holtzman (2005) stated that some emotionoriented coping strategies or styles are associated with several negative characteristics and younger age, and problem-oriented strategies, or task types, were associated with positive characteristics and older age. A person's personality, physical and environmental conditions, and the learning process he has gone through, also affect a person's ability to adapt to difficult situations. (Ali \& Anshori, 2004).

The habit of not drinking water from a well becomes one of the complications when there is a shortage of foodstuffs during isolation. Likewise, many family members will require separate thoughts and adjustments when supplies are running low due to isolation. Meanwhile, other habits such as providing education to the public about Covid will calm when they hear news about Covid.

\section{b. Conditions during Isolation}

Conditions during isolation include describing the initial state when it decided to isolate and the symptoms or conditions during isolation. The decision to undergo isolation based on positive PCR test results with or without symptoms, 
as experienced by the informants. Inf-1 should undergo isolation with no symptoms;

"Yes .. it's okay because I don't feel anything, yes I'm just ordinary," (Inf-1)

Meanwhile, Inf-2, at the start of the isolation, had already felt symptoms, namely feeling unwell and not having energy;

"... I'm really sleepy, I'm really sluggish ..."

"... I keep going home at ODP, I can't go anywhere, I'm at home but

I'm still working, so it hurts, it's just that my body is not feeling well," (Inf-2)

Another condition that affects the effort to conform during isolation is that activities during isolation cannot be as free as before isolation;

"... how come it's okay, it's just me because I'm lacking ma'am .." (Inf-2)

"... Together with the first beginning on the right and left cover" ... (Inf-2)

Activities usually carried out before isolation, such as sightseeing, became more limited because they were not allowed to leave the isolation area. Likewise, when family members undergo isolation in different places;

"... L entered Wednesday, we entered Friday. Yes, we are alone. " (Inf-1)

The implementation of isolation resulted in a reduction in the usual physical activity. This condition will affect one's mental health. As stated by Chu et al. (2014), physical activity has proven to reduce anxiety.

\section{c. Symptoms experienced during isolation}

Isolation is an action taken on someone positive for Covid-19, whether symptomatic or asymptomatic. So a person can be isolated even without symptoms. There are several cases whose symptoms only appear after carrying out isolation, as experienced by informants;

"In fact, when I was there, the drop was .." ( Inf-1)

Symptoms that appear when positive for Covid-19 can affect mental health conditions. The symptoms of Covid include increased body temperature, decreasing awareness to forget what has been done, such as robots, reduced oxygen in the blood, and a mismatch between thoughts and the activities. The informants also experienced shortness of breath, had no appetite, and felt weak, as told by the informants;

"I don't know what day is Friday or Saturday or Sunday. I asked

Mr. H, what day is it tho? So I'm like that robot"(Inf-1)

"Until I felt so hot" (Inf-1). 
"I'm not feeling well, tho" (Inf-2) "I'm not feeling well, tho" (Inf-2)

Through a literature review, Yuliana (2020) concluded that the common symptoms of individuals infected with Covid-19 include fever, cough, and difficulty breathing.

\section{Factors that cause anxiety}

\section{a. External Factors}

Anxiety during isolation can be caused by external factors, namely factors that come from outside the individual, including the psychological burden of the family (many family members are positive for Covid-19 and have to undergo isolation. Inf-2 said that three of 5 children must undergo isolation; likewise, Inf1 , one positive family, must be isolated.

"After the pandemic I tested positive, it was 2 negative, 3 positive" (Inf-2)

The existence of positive family members and undergoing isolation adds to the burden of individual thoughts and worries, in this case, a mother, such as an informant 1 whose child is undergoing isolation in a different place and informant 2 who is concerned about their condition children.

"L entered Wednesday, we entered Friday. Yes, we are alone "(Inf1)

"After the pandemic I tested positive, that's 2 negative, 3 positive," (Inf-2)

A large amount of work and family dependents with insufficient basic needs also cause increased anxiety. Likewise, with the environmental stigma/response to the condition of the isolated informants, some were afraid, some were angry so that which led to feelings of guilt and pressure.

"Even though I have to cut it at 11 o'clock, so this has to be sent. I'm confused at 9 o'clock, ma'am that soon, it turns out it's not like this, the model is all wrong, he said he said it was positive and from the puskesmas pick me up, wis already disbanded all. Complete stop "(Inf-2)

"I think it's the best, it's very good, only at the beginning, there was no water, you know. It's just plain water, there's no mother at all" (Inf-2)

"There were people who accepted me, either there were those who were afraid that they were brave again after that there was no transformation of the infection" (Inf-2)

"There were those who had time to blame and behave like that, at first they were angry, yes, maybe they were angry with me, who shared the same room with me too." (Inf-1)

As stated by Ali \& Asrori (2004), a person's personality, physical and environmental conditions, and the learning process he has gone through also affect 
a person's ability to adapt to difficult situations. Difficulty in adapting will cause anxiety.

\section{b. Internal factors}

The factors that cause anxiety that come from within the individual can be in the form of one's health, negative thoughts that often arise related to personal health, family and environmental stigma, as stated by the informants;

"Yes, maybe keep thinking, because Mr. H is a heart, so I'm afraid" (Inf-1)

"I do that, because previously it was reported that there was Covid 19, I was so afraid to ma'am" (Inf-2)

Tanoue et al. (2020) said that decreased psychological conditions caused the anxiety experienced by Covid-19 patients during isolation due to limited social contact with the environment, the emergence of quite severe physical symptoms, thinking about other family conditions / at home, and hear/see news of fallen victims. As concluded by Jannah et al. (2020), anxiety is strongly influenced by the patient's biological condition, such as coughing, hyperthermia, shortness of breath, and other physical discomfort.

\section{Symptoms of Anxiety}

Individuals who experience anxiety will show symptoms such as; Confused, worried, scared, restless and crying. Another symptom is that the individual is hesitant and dissatisfied with the treatment given and compared with services elsewhere.

"Yes, when my child came in, like Mr. H came in, there was an intravenous drip immediately, then there were injections of various kinds that were like the injection was very hot. So if e can be stable, you know. There's nothing there, right? "( Inf-1)

"I did like this, oh, later if anything happens," (Inf-1)

"But actually very scared" (Inf-2)

Nurjanah (2020) found that there were ten people $(33.3 \%)$ who had mentalemotional disorders in Covid pandemic clients (33.3\%) with the most complaints, namely feeling anxious, tense/worried (40\%), complaints of activity. / neglected daily tasks (37\%), loss of appetite (30\%), and poor sleep (30\%).

\section{Coping Strategy and Support}

Coping strategies are efforts made by individuals to overcome problems that involve themselves and their relationship with the environment to overcome or reduce anxiety. Coping strategies that can be carried out while undergoing isolation include; (1) Problem Focused Coping Strategy, consisting of; a) coping strategies to deal with the pandemic itself, such as wearing masks, maintaining distance, and implementing other health protocols;

"But at home near you also wear a mask" (Inf-1)

"Every day this house doesn't keep on working, the room is not perfect, the bathroom, the motorbikes in front are not perfect, everything, the door, the doorknob, just do not hold everything every 
day, to the kitchen chairs, the morning is just right. during gayenggayenge, but before I got hit, you know. " (Inf-2)

b) coping strategies to maintain a healthy body such as maintaining food intake, exercising, and sunbathing; c) coping to overcome needs by informing health workers or relatives to send food, d) coping to gain knowledge by asking for explanations from doctors; e) coping to overcome boredom by communicating with friends, video calling with family, praying in congregation and watching lectures on YouTube.

"So we video call 3 times for each meal" (Inf-1)

"With my 3 children, was asked if anyone could ping pong? Who likes what table tennis or badminton is like, that's how it was immediately given to you that table tennis had fought the officer. "(Inf-2)

f) informants also carry out activities to help and provide support to others, making them feel more valuable and happy.

"The fruit is a banana, so I'll give it to the cold one, sir, that's on purpose, we can't help but love someone. "Inf-2)

"Mutual support between the isolates. Number one surrender.

" (Inf-1)

(2). Emotion Coping Strategy, including support from family, relatives, friends, and the community in the form of positive acceptance, material assistance, advice, and efforts to motivate yourself with positive sentences (self-talk).

"Until L said you don't have to come home and have someone take care of it. L who gives support "(Inf-1)

"We ora will die right now" (Inf-2)

"I am not afraid of 19 but afraid that makes us get thoughts like that, oh like that of myself or who is this, alillahi wa Innalillahi roji'un innalillahi wa Innalillahi roji'un alhamdulillahirobbilalamin"

According to Ananda \& Apsari (2020), one of the effective ways to relieve stress is by using self-talk techniques to always think positively about the conditions at hand. By thinking and having positive suggestions, a person can reduce negative thoughts about himself or the surrounding environment and control emotions. Furthermore, social support will treat feelings of loneliness and loneliness in times of isolation; as found by Labraque et al. (2020), social support is a protective factor against loneliness.

Another coping strategy effort is spiritual effort, namely by accepting the situation and reality, giving thanks, surrendering to Allah's will, and returning everything to Allah. In addition, high efficacy can also help individuals overcome anxiety. 
"I finally gave up, I felt the point, oh my God, if this was my way, I was just begging to save Mr. H, but if this is my way, that's it" (Inf1)

"The child has not come out yet, but if the one who lives is left where I want to pray the water from where, it turns out that the delicious water is, but the water is cloudy, the water I am from home, whatever the situation, can accept it freely. He want to talk to me like that eat what is there already but there is someone who asked for this, ask for this, but I never, I never "

"All that is the best that is bestowed upon me, it is certain from Allah that the best for me one day we plan a negative God."

According to Yono et al. (2020), spiritual activities such as praying, dhikr, having good thoughts, making efforts, and praying a lot can prevent, overcome, and help people in dealing with anxiety disorders due to Covid-19.

\section{The effects of coping strategies}

A good coping strategy will make a person able to adapt to stressful situations to reduce and eliminate the anxiety that arises. The effects of coping strategies felt by the informants in this study, among others, feel calmer, feel that everything that is happening is God's best plan so that both physical and emotional health conditions will be better.

"Yes, I am more neutral than Mr. H" (Inf-1)

"Whatever the situation, you can accept it gracefully, that's how lillahita'ala is" (Inf-2)

Wahyuni et al. (2020) state that religiosity as a coping strategy can bring individuals to be better and optimistic, challenging, and accepting of their situations can make them feel calm in living reality.

\section{The wisdom of isolation}

However, undergoing isolation because positive Covid-19 can bring its wisdom for individuals, including; it is easier to meet or gather with family, other family members become stronger when compared to usual days and provide a means for self-introspection, as said by the informant;

"Because I was close to Mr. H, so with Mr. H it was even stronger" (Inf-1)

"That was it, when I was a kid I didn't prepare food, drink, money, I left my motorbike for work, I didn't fill up my motorbike, I didn't fill up all of this, it's not that I brought it all after going to school, I didn't go home at the same time. eat there Wa come in Come on maem Ma'am want to not tell Ma'am anyway, I want to recite the recitation on Wednesday, if before that, I was new to fasting, but apart from the fasting month, I can't talk about what I can say I can't be dizzy. I'm with you, at 1 pm together you meet me when the tailor is out for a massage, I will go to bed when I go to bed, Father, I'm not home yet I'm home I'm still sewing, I'm sleepy I'm 
still sewing No, it's not like that continues After that we can eat together together" (Inf-2)

Alexander (2020) stated that one of the lessons that can be taken from implementing isolation due to positive Covid-19 is that every individual has the awareness to maintain harmony in the family. The implementation of isolation that involved almost all members of the informant's family made the relationships and relationships in the family warm again. Every family member is easier to get together and has more concern for other members.

\section{CONCLUSION}

This study found five main themes related to anxiety and coping strategies used by individuals in undergoing isolation during the Covid-19 pandemic, namely conditions before and during isolation, factors that cause anxiety, symptoms of anxiety, coping strategies, and support effects of coping strategies, and wisdom undergo isolation. The success of various coping strategies also influences by the conditions of the difficulties experienced and the environment. In isolation situations during a pandemic, spiritual efforts, such as feelings of resignation and positive belief in God's provisions, seem to effectively reduce and overcome anxiety in undergoing isolation during the Covid-19 pandemic.

\section{REFERENCES}

Aldwin, C. M., \& Reverson, T. (1987). Does Coping Help? A Reexamination of The Relation Between Coping and mental health. Journal of Personality and Social Psychology, 53(2), 337-348. doi:10.1037/0022-3514.53.2.337

Alexander, Y. Y. (2020). Refleksi Atas Pandemi Corona dan Social Distancing. Dalam Covid-19 Dalam Ragam Tinjauan Perspektif (hal. 471-477). Depok: Mbridge Press.

Ali, M., \& Asrori, M. (2012). Psikologi Remaja Perkembangan peserta Didik. Jakarta: PT. Bumi Aksara.

Ananda, s., \& Apsari, N. C. (2020). Mengatasi Stress pada remaja saat pandemi covid-19 dengan teknik selftalk. Prosiding Penelitian \& pengabdian Kepada Masyarakat, (hal. 248-256).

Antara. (2020). Diambil kembali dari https://tirto.id/survei-643-dari-1522-orang cemas-depresi-karena covid-19-fgPG.

Aufar, A. F., \& Raharjo, S. T. (2020). Kegiatan Relaksasi Sebagai Coping Stress di Masa Pandemi Covid-19. Jurnal kolaborasi Resolusi Konflik.2(2), 157163.

Brooks, S., Amlot, R., Rubin, G. J., \& Greenberg, N. (2020). Psychological resilience and post-traumatic growth in disaster-exposed organizations: An overview of the literature. BMJ Mil Health, 166(1), 52-56. doi:10.1136/jramc-2017-000876 
Chu, A., Koh, D., Moy, M. M., \& Muller-Riemenescheider, F. (2014). Do Workplace Physical Activity Interventions Improve Mental Health Outcomes?. Occupational Medicine, 64, 235-245. doi:10.1093/ocumed/kqu045

Delongis, A., \& Holtzman, S. (2005). The Role of Stress, Social Support, and Personality in Coping. Journal of Personality, 73(6), 1633-1656. doi:DOI:10.1111/j.1467-6494.2005.00361.x

Jannah, A. R., Jatimi, A., Azizah, M. J., Munir, Z., \& Rahman, H. F. (2020). Kecemasan Pasien Covid-19: A.Systematic Review. Jurnal penelitian Kesehatan Suara Forikes, 11; 3337.http://dx.doi.org/10.33846/sf11nk406.

Kaplan, H., Sadock, B. J., \& Grebb, J. A. (2010). Sinopsis Psikiatri: Ilmu Pengetahuan Perilaku Psikiatri Klinis (2 ed.). (I. M. S., Penyunt.) Jakarta: Bina Rupa Aksara.

Lazarus, R. S. (1991). Emotion and adaptation.

Lazarus, R., \& Folkman, S. (1984). Stress, appraisal, and coping. Springer. doi: Google Scholar

Mai, M., Wang, J., Xia, D., Guo, X., Li, F., Chen, Y., . . Z Zhang, H. (2020). Survey of Anxiety and Depression in Patients with Suspected and Confirmed Cases of Covid-19 During Hospitalization and Isolation. http://doi.org/10.21203/rs.17959/v1.

Moloeng, L. (2011). Metodologi Penelitian Kualitatif Edisi Revisi. Bandung: PT. Remaja Rosdakarya.

Muslim, M. (2020). Manajemen Stress Pada Masa Pandemi Covid-19. Jurnal Managemen Bisnis, 192-201.

Nicolas, M., \& Sandal, G. M. (2013). Mars-105 study: Time-courses and relationships between coping,. Journal of Environmental Psychology, 35, 52-58. doi:10.1016/j.jenvp.2013.05.001

Nurjanah, S. (2020). Gangguan Mental Emosional Pada Klien Pandemi Covid-19 di Rumah Karantina. Jurnal Ilmu Keperawatan Jiwa., 3(3), 329-334.

Oktavia, W., \& Hayati, N. (2020). Pola Karakteristik Ragam Bahasa Istilah Pada masa Pandemi Covid-19 (Corona Virus Disease 2019). Jurnal Bahasa, sastra, dan Pengajarannya, 1(1), 1-15.

PDSKJI. (2020). Lima bulan Pandemi covid di Indonesia. Retrieved July 29, 2021, from http://pdskji.org/home

RN, L. J., Falguera, C. C., \& Santos, J. A. (2020). Social-Emotional Loneliness among College Students during The Covid-19 Pandemic: The Perspective Role of Coping Behaviours, Social Support, and Personel Resilience. Perspect Psychiatric Care, 2021, 1-7. doi:10.1111/ppc.12721 
Rosyanti, L., \& Hadi, I. (2020). Dampak Psikologis dalam Memberikan Perawatan dan Layanan Kesehatan Pasien Covid-19 pada Tenaga Profesional Kesehatan. HIJP.12(1), 107-130.

Tanoue, Y., Nomura, S., Yoneoka, D., Kawashima, T., Eguchi, A., \& Shi, S. (2020). Mental Health of Family, Friends, and co-Workers of Covid-19 patients in Japan. Psychiatry Res. , http://doi.org/10.1016/j.psychres.2020.113067.

Wahyuni, I., Sutarno, \& Andika, R. (2020). Hubungan Tingkat religiusitas dengan Tingkat kecemasan Mahasiswa di Masa Pandemi Covid-19. Jurnal Kesehatan Al-Irsyad, XIII(2).131-144.

Weis, R., Ray, S. D., \& Coben, T. A. (2020). Mindfulness as a way to Cope with COVID-19-Related Stress and Anxiety. Couns Psychother Res, 00, 1-11. doi:10.1002/capr.12375

WHO. (2019). Mental Health \& Covid-19. Retrieved July 29, 2021, from ] https://www.who.int/teams/mental-health-and-substance-use/covid-19.

WHO. (2020). Pertanyaan dan Jawaban terkait Coronavirus. Retrieved July 29, 2021 from https: //www.who.int/indonesia/news/novel-coronavirus/qa/qa-forpublic

Yono, Y., Rusmana, I., \& Noviyanty, H. (2020). Psikoterapi Spiritual dan pendidikan Islam dalam Mengatasi dan Menghadapi Gangguan Anciety Disorder di Saat dan Pasca Covid-19. Jurnal Sosial dan Budaya Syar-i, 7(8).v.

Yuliana. (2020). Corona Virus Disease (COVID-19): Study Literatur. Wellness and Healthy Magazine, 2(1), -192. 